\title{
Pretrial hippocampal $\theta$-state differentiates single-unit response profiles during rabbit trace eyeblink conditioning
}

\author{
Joseph J. Cicchese, ${ }^{1}$ Ryan D. Darling, ${ }^{2}$ and Stephen D. Berry ${ }^{1}$ \\ ${ }^{1}$ Department of Psychology and Center for Neuroscience, Miami University, Oxford, Ohio 45056, USA; ${ }^{2}$ Department of Neurobiology \\ and Anatomical Sciences, University of Mississippi Medical Center, Jackson, Mississippi 39216, USA
}

\begin{abstract}
Eyeblink conditioning given in the explicit presence of hippocampal $\theta$ results in accelerated learning and enhanced multipleunit responses, with slower learning and suppression of unit activity under non- $\theta$ conditions. Recordings from putative pyramidal cells during $\theta$-contingent training show that pretrial $\theta$-state is linked to the probability of firing increases versus decreases rather than to the magnitude of such responses. These findings suggest that the learning facilitation during $\theta$ may be due to the recruitment of additional neurons that increase their firing rate during trials.
\end{abstract}

Rabbit eyeblink conditioning (EBC) is a well-characterized associative learning task that has provided crucial insights into the neurobiology of mammalian learning and memory (Christian and Thompson 2003). The hippocampus is necessary for trace EBC and displays both excitatory and inhibitory learning-related neural responses during behaviorally significant trial periods (Berger et al. 1983; Weiss et al. 1996; McEchron and Disterhoft 1997, 1999). Hippocampal local field potentials (LFPs) are dominated in the rabbit by $\theta$, a 3-7 Hz oscillatory potential that is highly correlated with patterns of single-unit firing (Fox and Ranck 1981; Klausberger and Somogyi 2008). The mechanisms of $\theta$ generation and its relationship to learning have been studied extensively (Buzsáki 2002; Colgin 2013). This includes its phasic coordination with extra-hippocampal network activity (Hyman et al. 2003; Siapas et al. 2005; Hoffmann and Berry 2009) and, when pretrial $\theta$-state is assessed, with the speed of behavioral learning (Berry and Thompson 1978; Nokia et al. 2008).

The relationship between $\theta$ and $\mathrm{EBC}$ has been confirmed in studies that disrupt hippocampal $\theta$ via lesions or pharmacological inactivation to inhibit learning (Solomon et al. 1983; Salvatierra and Berry 1989; Kaneko and Thompson 1997) and in studies that elicit or enhance $\theta$ to boost learning (Berry and Swain 1989). However, all of these studies produced unnatural (nonphysiological) alterations to the LFP, disrupting the natural ebb and flow that some believe to be essential to the role of $\theta$ in cognitive processes (Buzsáki 2006; Berry and Hoffmann 2011). Importantly, Scarlett et al. (2004) cautioned that $\theta$ induced by medial septum stimulation can profoundly distort the normal physiological response patterns in $\theta$-related hippocampal cells as well as their relation to the induced $\theta$ LFP.

Seager et al. (2002) developed a brain-computer interface to control the naturally occurring oscillations by restricting EBC trials to either the presence $(\mathrm{T}+)$ or absence $(\mathrm{T}-)$ of real-time hippocampal $\theta$, with animals in the $\mathrm{T}+$ condition learning significantly faster than animals in the $\mathrm{T}-$ condition. This finding has been replicated (Griffin et al. 2004; Asaka et al. 2005) and extended to show that $\mathrm{T}+$ training leads to an increase in hippocampal multiple-unit responses (Griffin et al. 2004; Darling et al. 2011), reduction of age-related memory impairment (Asaka et al. 2005), enhancement in neural activity of the prefrontal cortex (Darling

Corresponding author: berrysd@miamioh.edu

Article is online at http://www.learnmem.org/cgi/doi/10.1101/Im.038216.115. et al. 2011), and precise synchronization of hippocampal and cerebellar LFPs at $\theta$ frequency (Hoffmann and Berry 2009).

We have reported striking increases in stimulus-evoked activity during hippocampal $\theta$ in both hippocampus and prefrontal cortex; however, it remains unclear whether the greater average multiple-unit responses in the $\mathrm{T}+$ condition are caused by a large firing rate increase in a few critical cells or by an increase in the overall number of cells showing excitation. Early rabbit EBC work demonstrated pyramidal cells to be the major contributor to learning-dependent changes in multiple-unit activity (Berger and Thompson 1978; Berger et al. 1983). In order to more fully explain group differences in our multiple-unit studies, it is essential to characterize individual pyramidal cell responses in terms of their qualitative nature (rate increasing/decreasing) as well as response magnitude. The current study classified putative pyramidal cell firing in the hippocampus during trace EBC using $\theta$ contingent training to compare unit responses in $\theta$ and non- $\theta$ states, corresponding to rapid and slow behavioral learning, respectively.

Microdrives consisting of six independently moveable tetrodes were surgically implanted into the dorsal hippocampus (CA1; $4.5 \mathrm{~mm}$ caudal and $5.5 \mathrm{~mm}$ lateral to bregma) of nine New Zealand rabbits (Oryctolagus cuniculus) under isoflurane anesthesia. Rabbits were randomly assigned to two groups: paired tone/airpuff trials in the presence $(\mathrm{T}+, n=5)$ or absence $(\mathrm{T}-$, $n=4$ ) of hippocampal $\theta$. The triggering channel was filtered (1-25 Hz) with a Neuralynx Inc. (Lynx-8) amplifier and output to a National Instruments PCI-6221 data acquisition board to analyze the LFP with the previously described LabVIEW program (Seager et al. 2002). The LabVIEW program calculated a ratio of power at $\theta(3.5-8.5 \mathrm{~Hz})$ to non- $\theta(0.5-3.5$ and $8.5-22 \mathrm{~Hz})$ for 640 -msec running time intervals, offset by $160 \mathrm{msec}$. In the $\mathrm{T}+$ condition, trials were triggered if the ratio exceeded 1.0 for three consecutive intervals (Fig. 1A) and in the $\mathrm{T}-$ condition if the ratio fell below 0.3 for three consecutive intervals (Fig. 1B).

\footnotetext{
(C) 2015 Cicchese et al. This article is distributed exclusively by Cold Spring Harbor Laboratory Press for the first 12 months after the full-issue publication date (see http://learnmem.cshlp.org/site/misc/terms.xhtml). After 12 months, it is available under a Creative Commons License (AttributionNonCommercial 4.0 International), as described at http://creativecommons. org/licenses/by-nc/4.0/.
} 
A

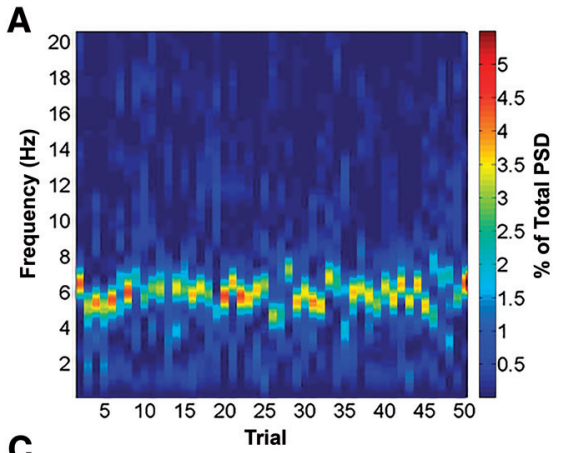

C

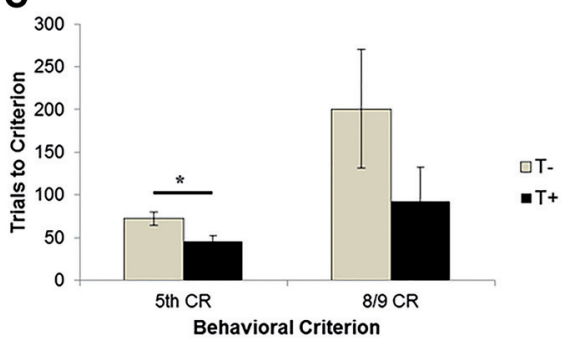

Figure 1. Surface plots showing representative power spectral densities for $(A)$ a $T+$ animal and $(B)$ $\mathrm{T}-$ animal within a $0-20 \mathrm{~Hz}$ bandwidth for one training session. The $\mathrm{T}+$ subject showed high $\theta$ throughout each trial in the session, while the T- subject showed low $\theta$ and a mix of high delta and $\alpha$ throughout. These $\mathrm{T}+$ and $\mathrm{T}-$ patterns of activity are precisely controlled by the $\mathrm{BCl}$ in each group. (C) T+ animals required fewer trials to reach the fifth $C R$ criterion than $\mathrm{T}-$ animals $(P<$ $0.05)$, with no significant difference in trials to reach $8 / 9$ CRs $(P>0.05)$.

Trace EBC trials consisted of a 100-msec tone, 500-msec stimulus-free trace period, and 100-msec corneal airpuff. The intertrial interval was under control of the hippocampal LFPs, with a minimum of $60 \mathrm{sec}$. Each session lasted for a maximum of $90 \mathrm{~min}$ or 50 trials $(\mathrm{T}+: M=41.884$ trials/session, $\mathrm{T}-: M=$ 43.5 trials/session). Rabbits were trained to a criterion of $70 \%$ CRs in a session. Behavioral effects compared the number of trials to reach an early criterion of 5 th CR, a measure of initial acquisition of the association (Thompson et al. 1979; Prokasy 1987; Griffin et al. 2004), and a late criterion of eight CRs out of nine consecutive trials, a measure of asymptotic learning (Gormezano et al. 1987). Unit responding during three learning stages was evaluated: training occurring on or before performance of fifth CR (early learning), days following fifth CR and occurring on or before performance of 8/9 CRs (late learning), and all days following 8/9 CR performance (asymptotic performance). Following training, electrode locations were marked by passing a $50 \mu \mathrm{A} \mathrm{DC}$ current for $10 \mathrm{sec}$. Animals were sacrificed and brains stained with Cresyl violet. All included records were from neurons located in or between stratum oriens and stratum radiatum of dorsal CA1.

Sorting was conducted using Plexon Offline Sorter. Microdrives were typically manipulated prior to each training day for optimal signal-to-noise ratio of single-units, allowing more confidence in statistical independence for units over training days. If a tetrode was not advanced, isolated units from that day were compared with units from the previous day and only units with clearly different waveforms were included as independent observations. Following isolation, spike rate and duration were calculated for cell-type classification using standard criteria in the field (Ranck 1973; Fox and Ranck 1981; Weiss et al. 1996; McEchron and Disterhoft 1997). Recordings were obtained from 593 units throughout training; units with spike durations $>0.3 \mathrm{msec}$ and firing rates $<6 \mathrm{~Hz}$ were considered putative pyramidal cells. A total of 369 isolated units met these criteria (duration: $M=0.516 \mathrm{msec}, \mathrm{SD}=$ 0.111 ; Frequency: $M=1.538 \mathrm{~Hz}, \mathrm{SD}=1.549$ ), the remaining units
A $2(\theta$ condition $) \times 3$ (learning phase) ANOVA was conducted on the 100-msec tone period average standard score. There was a main effect of $\theta$ condition with cells in the $\mathrm{T}+$ condition showing a greater response than those in the $\mathrm{T}-$ condition, $F_{(1,363)}=$ $10.403, P<0.001$, and a $\theta$ by phase interaction, $F_{(2,363)}=3.783$, $P=0.024$. To address the significant interaction, Bonferroni corrected tests of simple main effects were conducted to identify effects of $\theta$ at the different learning phases. There was an effect of $\theta$ at the early learning phase with cells in the T + condition having a greater average response than those in the $\mathrm{T}-$ condition, $F_{(1,363)}=12.600, P<0.016$; however, there were no $\theta$-contingent differences at the late or asymptotic phases, $P \mathrm{~S}>0.05$ (Fig. 2C).

During the 500-msec trace period, the $2 \times 3$ ANOVA revealed a main effect of $\theta$ condition with a greater unit response in $\mathrm{T}+$ animals than in $\mathrm{T}-$ animals, $F_{(1,363)}=5.495, P=0.020$, and a $\theta$ by phase interaction, $F_{(2,363)}=5.215, P=0.006$. Bonferroni corrected tests of simple main effects revealed that cells in the $\mathrm{T}+$ condition showed a greater average response than those in the $\mathrm{T}-$ condition in the early phase, $F_{(1,363)}=13.169, P<0.016$, but not in the late or asymptotic phases, $P \mathrm{~s}>0.05$ (Fig. 2D). No significant group differences were observed during the airpuff period.

To assess whether the observed standard score differences reflect large changes in firing rate of few neurons versus differences in the number of cells showing excitation/inhibition, we used Mann-Whitney $U$ tests to classify cells according to significant rate differences between the relevant trial epoch (tone or trace) and the pre-CS baseline (Hattori et al. 2015). Units were then identified as rate decreasing (RD) or increasing (RI) for further analyses (Fig. 3A,B).

A 2 ( $\theta$ condition $) \times 2$ (response direction) $\chi^{2}$ test was significant for the early learning phase tone period $\chi^{2}{ }_{(3, N=40)}=21.641$, $P<0.001$. Bonferroni corrected comparisons showed that RI cells were more common in the $\mathrm{T}+$ condition $(15 / 40 ; 37.500 \%)$ than in the $\mathrm{T}-$ condition $(7 / 53 ; 13.208 \%), \quad \chi_{(1, N=22)}^{2}=$ 12.716, $P<0.001$, and RD cells were more common in the 
A
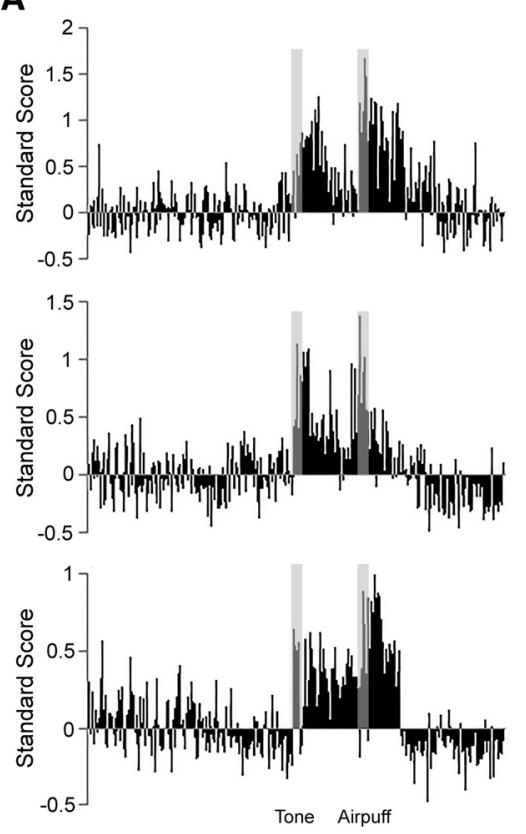

C

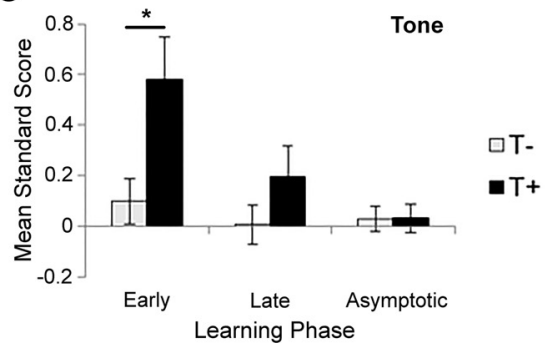

B
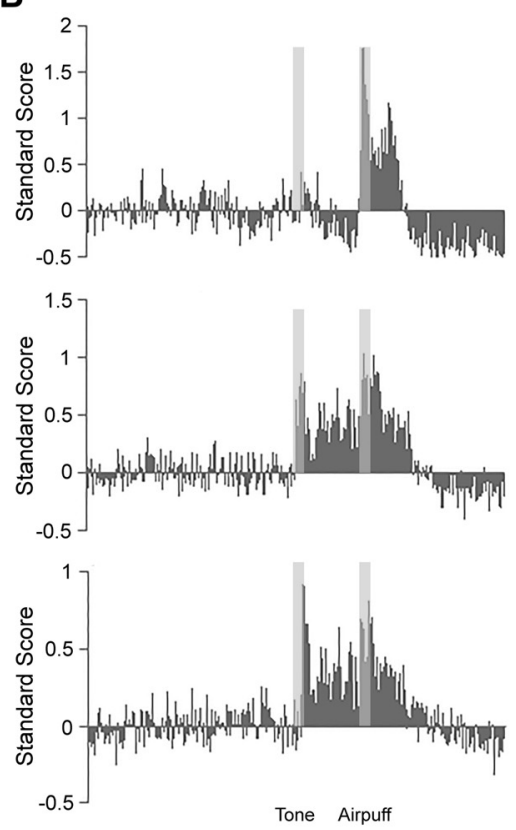

D

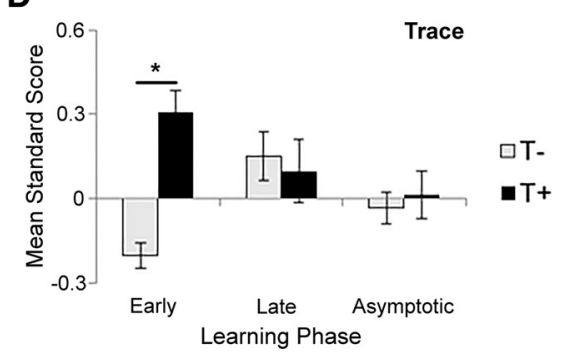

Figure 2. Perievent histograms with $10-\mathrm{msec}$ bins during the early (top), late (middle), and asymptotic (bottom) phases averaged across all units for $\mathrm{T}+(A)$ and $\mathrm{T}-(B)$ animals. The gray shaded columns indicate presentation of the conditioning stimuli (tone and airpuff). (C) Mean standard scores during the tone presentation for each learning phase. Cells in $\mathrm{T}+$ condition had a greater response than those in the $\mathrm{T}-$ condition during the early learning phase. $(D)$ Mean standard scores during the trace period for each learning phase. Cells in the $\mathrm{T}+$ condition had a greater response than those in the $\mathrm{T}-$ condition during the early learning phase. $\left(^{*}\right) P<0.016$, Bonferroni corrected $\alpha$.

$\mathrm{T}-$ condition $(14 / 53 ; 26.415 \%)$ than in the $\mathrm{T}+$ condition $(4 / 40$; $10.000 \%), \chi^{2}(1, N=18)=7.097, P=0.008$ (Fig. 3C). Bonferroni corrected $t$-tests were conducted to identify $\theta$-contingent differences in standard score magnitude for RI and RD cells. These tests revealed no significant differences in average standard scores, $P \mathrm{~s}>$ 0.05 (Fig. 3D).

Similarly, the $2 \times 2 \chi^{2}$ test was significant for the trace period $\chi^{2}{ }_{(3, N=25)}=16.994, P<0.001$. Cells in the $\mathrm{T}+$ condition were more likely to be RI $(10 / 40 ; 25.000 \%)$ than those in the T- condition $(3 / 53 ; 5.660 \%), \chi_{(1, N=13)}^{2}=13.640, P<0.001$, while no $\theta$-related difference existed in RD cells during the trace period, $P>0.05$ (Fig. 3E). There were no $\theta$-contingent differences in standard score magnitude for RI or RD cells, $P$ s $>0.05$ (Fig. 3F).

In the present study, the beneficial effect of $\theta$ on behavioral learning was accompanied by a greater response of putative pyramidal cells in the $\mathrm{T}+$ condition during both the tone and trace periods early in learning. The increase in $\mathrm{T}+$ putative pyramidal cell responsiveness replicates and helps explain previous work in our laboratory showing multiple-unit response increases in the $\mathrm{T}+$ condition during the trace period (Griffin et al. 2004; Darling et al. 2011). By sorting individual cells into groups based on qual- itative response type (RI/RD), we found that RI cells were more likely to respond during the tone and trace periods in the $\mathrm{T}+$ condition compared with the $\mathrm{T}-$. In contrast, the $\mathrm{T}-$ condition favored the development of inhibitory (RD) responses. This double dissociation underscores a significant impact of $\theta$ condition on whether the dominant unit response was excitatory or inhibitory. Importantly, there were no differences in the magnitude of RI or RD responses between $\theta$ conditions. Thus, a major finding here is that $\theta$-state corresponded to response type rather than response magnitude of putative pyramidal cells.

Our data suggest that previously reported increases in multiple-unit responses during $\theta$-triggered $\mathrm{EBC}$ might be attributed more to a recruitment of additional excitatory (RI) units rather than a large increase in rate for any particular unit. This finding helps interpret hippocampal multiple-unit recordings, which have been shown to reflect pyramidal cell firing (Berger and Thompson 1978; Berger et al. 1983). In other words, a large increase in multiple-unit standard scores suggests more cells showing excitatory responses and fewer cells inhibited. This is consistent with a recent study showing that cells are more likely to increase firing in conditioned than pseudoconditioned animals, with no effect of training on magnitude of RI responses (Hattori et al. 2015), and extends this finding to conditioned animals learning at different rates under $\theta$ and non- $\theta$ conditions. While previous work in rabbit EBC has shown large increases in multiple- and single-unit responding (Berger et al. 1976, 1983; Weiss et al. 1996; McEchron and Disterhoft 1997, 1999), the impact of $\theta$-state on the single-unit code in CA1 may act more subtly, yet importantly, by changing the relative proportion of pyramidal cells displaying significant excitation to the conditioning stimuli, ultimately guiding adaptive behavior. This conclusion follows similar logic to work showing that activation-dependent inhibition of pyramidal cells is caused by additional basket cells inhibiting a given neuron, rather than a large increase in firing rate of any one basket cell (Sik et al. 1995). McEchron and Disterhoft $(1997,1999)$ identified a number of pyramidal cell response profiles in CA1, showing that inhibitory responses are more likely to occur during EBC. Our work suggests that training in the explicit presence of $\theta$ allows for a greater proportion of excitatory response profiles in putative pyramidal cells, possibly contributing to fewer trials needed for the early learning criterion. In the absence of $\theta$, this proportion is less than optimal, resulting in impaired learning.

Our findings provide important empirical support for a prominent model of $\theta$ 's role in learning. Hasselmo et al. (2002) have proposed a model of associative learning in which the $\theta$ rhythm provides separate encoding and retrieval phases. These separate phases are characterized by different responding of identified cell types. For example, it is expected that pyramidal cells will fire during the retrieval phase, but not the encoding. 
A
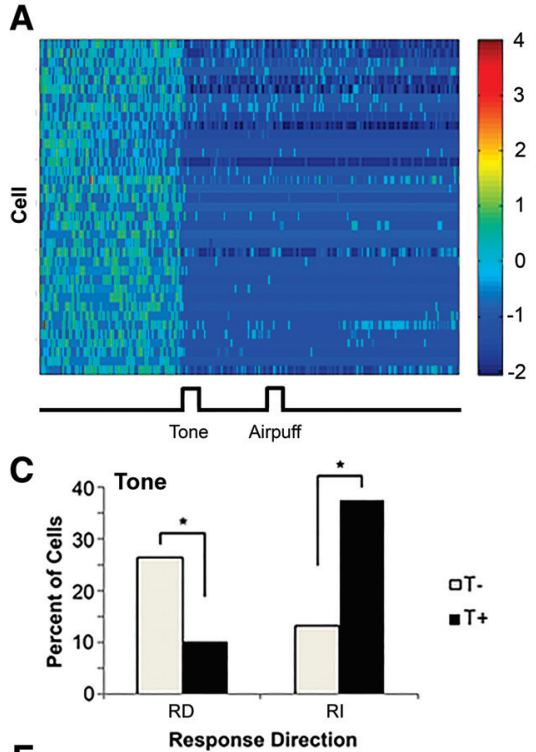

E

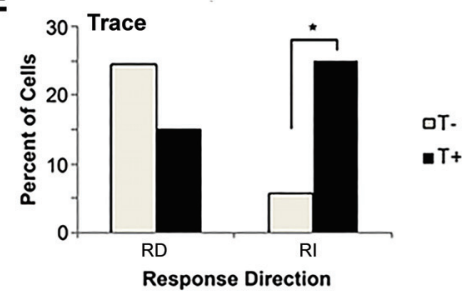

B

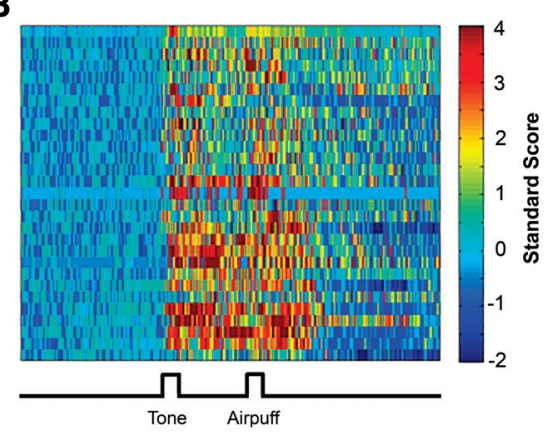

D

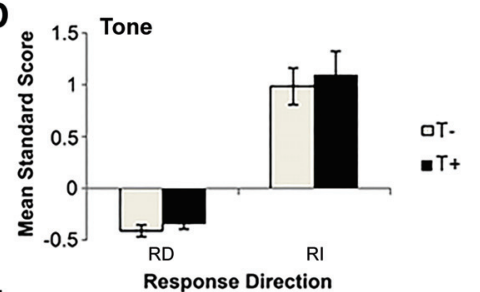

$\mathbf{F}$

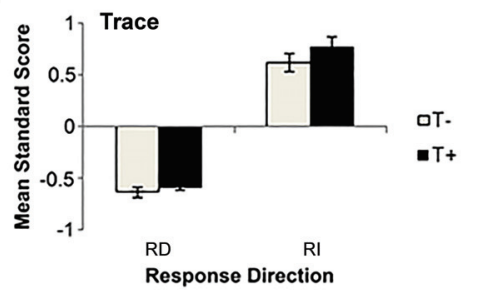

Figure 3. Surface plots showing the standard scores (10-msec bins) averaged across a session for all $(A)$ rate decreasing $(\mathrm{RD})(B)$ and rate increasing (RI) cells (truncated to four for illustration purposes). (C) A greater percentage of cells in the T+ condition were RI during the tone than in the T-condition and a greater percentage of $\mathrm{T}-$ cells were RD during the tone than in the $\mathrm{T}+$ condition. $(D)$ There were no $\theta$-contingent differences in mean standard score for RD or RI cells during presentation of the tone. $(E)$ During the trace period, a greater percentage of cells were RI in the T+ condition than in the $\mathrm{T}-$ condition, but no difference existed in RD cells. $(F)$ There were no $\theta$-contingent differences in mean standard score for RD or RI cells during the trace period. $\left(^{*}\right) P<0.025$, Bonferroni corrected $\alpha$.

Interneurons, depending on their relation to $\theta$ and pyramidal cell firing, will display heterogeneous response profiles. In interpreting such data, it is important to know whether a given cell type is increasing its firing, as well as the magnitude of its response. Our finding that $\theta$ can modulate putative pyramidal cell response type provides a candidate mechanism by which the optimal proportion of cells firing during the learning and retrieval phases is achieved, resulting in more rapid acquisition of the behavioral response. The lack of quantitative (magnitude) differences in RI/RD units between $\theta$ and non- $\theta$ groups in the current study strongly suggests that firing rates per se are not related to the behavioral benefit of $\theta$ in the hippocampus. Given the typical usage of cellular firing rates as evidence for the engagement of neurons in various tasks and cognitive processes, it is now clearly important to explore the significance of qualitative response type as a critical aspect of the multineuronal code.

\section{Acknowledgments}

This material is based upon work supported by the National Science Foundation under Grant nos. IOB-0517575 and IOS-1121969 (S.D.B.). We thank Lynn Johnson, Barry Landrum, and Dr. Amy Griffin for their technical contribution.

\section{References}

Asaka Y, Mauldin KN, Griffin AL, Seager MA, Shurell E, Berry SD. 2005. Nonpharmacological amelioration of age-related learning deficits: the impact of hippocampal $\theta$-triggered training. Proc Natl Acad Sci 102: 13284-13288.

Berger TW, Thompson RF. 1978. Identification of pyramidal cells as the critical elements in hippocampal neuronal plasticity during learning. Proc Natl Acad Sci 75: 1572-1576.

Berger TW, Alger B, Thompson RF. 1976. Neuronal substrate of classical conditioning in the hippocampus. Science 192: $483-455$.

Berger TW, Rinaldi PC, Weisz DJ, Thompson RF. 1983. Single-unit analysis of different hippocampal cell types during classical conditioning of rabbit nictitating membrane response. J Neurophysiol 50: 1197-1219.

Berry SD, Hoffmann LC. 2011. Hippocampal $\theta$-dependent eyeblink classical conditioning: coordination of a distributed learning system. Neurobiol Learn Mem 95: 185-189.

Berry SD, Swain RA. 1989. Water deprivation optimizes hippocampal activity and facilitates nictitating membrane conditioning. Behav Neurosci 103: 71-76.

Berry SD, Thompson RF. 1978. Prediction of learning rate from the hippocampal electroencephalogram. Science 200: $1298-1300$.

Buzsáki G. 2002. $\theta$ Oscillations in the hippocampus. Neuron 33: 325-340.

Buzsáki G. 2006. Rhythms of the brain. Oxford University Press, New York.

Christian KM, Thompson RF. 2003. Neural substrates of eyeblink conditioning: acquisition and retention. Learn Mem 10: $427-455$.

Colgin LL. 2013. Mechanisms and functions of $\theta$ rhythms. Annu Rev Neurosci 36: 295-312.

Darling RD, Takatsuki K, Griffin AL, Berry SD. 2011. Eyeblink conditioning contingent on hippocampal $\theta$ enhances hippocampal and medial prefrontal responses. $J$ Neurophysiol 105: 2213-2224.

Fox SE, Ranck JB Jr. 1981. Electrophysiological characteristics of hippocampal complex-spike cells and $\theta$ cells. Exp Brain Res 41: 399-410.

Gormezano I, Prokasy WF, Thompson RF. 1987. Classical conditioning, 3rd ed. Erlbaum, New Jersey.

Griffin AL, Asaka Y, Darling RD, Berry SD. 2004. $\theta$-Contingent trial presentation accelerates learning rate and enhances hippocampal plasticity during trace eyeblink conditioning. Behav Neurosci 118: 403-411.

Hasselmo ME, Bodelón C, Wyble BP. 2002. A proposed function for hippocampal $\theta$ rhythm: separate phases of encoding and retrieval enhance reversal of prior learning. Neural Comput 14: 793-817.

Hattori S, Chen L, Weiss C, Disterhoft JF. 2015. Robust hippocampal responsively during retrieval of consolidated associative memory. Hippocampus 25: 655-669.

Hoffmann L, Berry SD. 2009. Cerebellar $\theta$ oscillations are synchronized during hippocampal $\theta$-contingent trace conditioning. Proc Natl Acad Sci 106: $21371-21376$.

Hyman JM, Wyble BP, Goyal V, Rossi CA, Hasselmo ME. 2003. Stimulation in hippocampal region CA1 in behaving rats yields long-term potentiation when delivered to the peak of $\theta$ and long-term depression when delivered to the trough. J Neurosci 23: 11725-11731.

Kaneko T, Thompson RF. 1997. Disruption of trace conditioning of the nictitating membrane response in rabbits by central cholinergic blockade. Psychopharmacology (Berl) 131: 161-166.

Klausberger T, Somogyi P. 2008. Neuronal diversity and temporal dynamics: the unity of hippocampal circuit operations. Science $\mathbf{3 2 1}$ : 53-57.

McEchron MD, Disterhoft JF. 1997. Sequence of single neuron changes in CA1 hippocampus of rabbits during acquisition of trace eyeblink conditioned responses. J Neurophysiol 78: 1030-1044. 
McEchron MD, Disterhoft JF. 1999. Hippocampal encoding of non-spatial trace conditioning. Hippocampus 9: 385-396.

Nokia MS, Penttonen M, Korhonen T, Wikgren J. 2008. Hippocampal $\theta$ $(3-8 \mathrm{~Hz})$ activity during classical eyeblink conditioning in rabbits. Neurobiol Learn Mem 90: 62-70.

Prokasy WF. 1987. A perspective on the acquisition of skeletal responses employing the Pavlovian paradigm. In Classical conditioning, 3rd ed. (ed. Gormezano I, Prokasy WF, Thompson RF), pp. 287-318. Erlbaum, New Jersey.

Ranck JB Jr. 1973. Studies on single neurons in dorsal hippocampal formation and septum in unrestrained rats. Part I. Behavioral correlates and firing repertoires. Exp Neurol 41: 461-531.

Salvatierra AT, Berry SD. 1989. Scopolamine disruption of septo-hippocampal activity and classical conditioning. Behav Neurosci 103: $715-721$.

Scarlett D, Dypvik AT, Bland BH. 2004. Comparison of spontaneous and septally driven hippocampal $\theta$ field and $\theta$-related cellular activity. Hippocampus 14: 99-106.

Seager MA, Johnson LD, Chabot ES, Asaka Y, Berry SD. 2002. Oscillatory brain states and learning: impact of hippocampal $\theta$-contingent training. Proc Natl Acad Sci 99: 1616-1620.
Siapas AG, Lubenov EV, Wilson MA. 2005. Prefrontal phase locking to hippocampal $\theta$ oscillations. Neuron 46: 141-151.

Sik A, Penttonen M, Ylinen A, Buzsaki G. 1995. Hippocampal CA1 interneurons: an in vivo intracellular labeling study. J Neurosci 15: $6651-6665$.

Solomon PR, Solomon SD, Vander Schaaf E, Perry HE. 1983. Altered activity in the hippocampus is more detrimental to classical conditioning than removing the structure. Science 220: 329-331.

Thompson RF, Berry SD, Rinaldi PC, Berger TW. 1979. Habituation and the orienting reflex: the dual process revisited. In The orienting response in human (ed. Kimmel HD, Van Olst EH, Orlebeke JF), pp. 21-60. Erlbaum, New Jersey.

Weiss C, Kronforst-Collins MA, Disterhoft JF. 1996. Activity of hippocampal pyramidal neurons during trace eyeblink conditioning. Hippocampus 6: 192-209.

Received January 18, 2015; accepted in revised form April 23, 2015. 


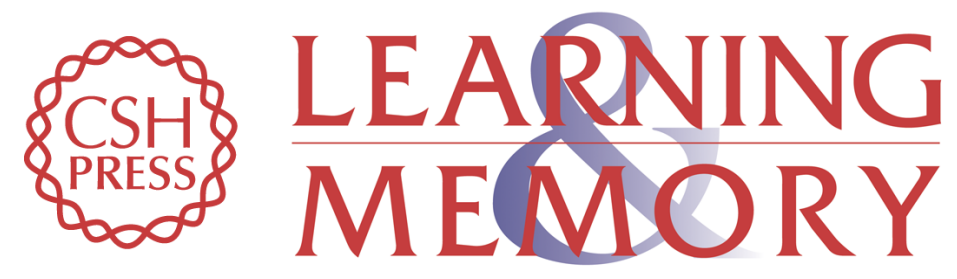

\title{
Pretrial hippocampal $\theta$-state differentiates single-unit response profiles during rabbit trace eyeblink conditioning
}

\author{
Joseph J. Cicchese, Ryan D. Darling and Stephen D. Berry
}

Learn. Mem. 2015, 22:

Access the most recent version at doi:10.1101/Im.038216.115

\begin{aligned} & \hline References $\begin{array}{l}\text { This article cites } 30 \text { articles, } 11 \text { of which can be accessed free at: } \\ \text { http://learnmem.cshlp.org/content/22/7/318.full.html\#ref-list-1 }\end{array} \\ & \begin{array}{r}\text { Creative } \\ \text { Commons } \\ \text { License }\end{array} \begin{array}{l}\text { This article is distributed exclusively by Cold Spring Harbor Laboratory Press for the } \\ \text { first } 12 \text { months after the full-issue publication date (see } \\ \text { http://learnmem.cshlp.org/site/misc/terms.xhtml). After } 12 \text { months, it is available under } \\ \text { a Creative Commons License (Attribution-NonCommercial } 4.0 \text { International), as } \\ \text { described at http://creativecommons.org/licenses/by-nc/4.0/. }\end{array} \\ & \begin{array}{c}\text { Receive free email alerts when new articles cite this article - sign up in the box at the } \\ \text { top right corner of the article or click here. }\end{array} \\ & \begin{array}{c}\text { Service } \\ \text { terting }\end{array}\end{aligned}$

